\section{Đorđe Božović}

Univerzitet u Beogradu

Filološki fakultet
004:929 Туринг А.

https://doi.org/10.18485/climb.2017.5.2.ch13

\title{
ROD I JEZIK I MAŠINSKA INTELIGENCIJA
}

\begin{abstract}
Sažetak
U radu se ističu socijalne osnove Turingove epistemologije mašinske inteligencije. Pokazuje se kako je Turingova zamisao o inteligentnim računarima usko povezana $s$ konceptom performativnosti u domeni jezika i roda, odnosno kako su "tvrde" naučne paradigme poput Al motivisane i oblikovane idejama iz humanistike i kulture.

Ključne reči: Turingov test, socijalne epistemologije, lingvistička epistemologija, rod i performativnost, istorija ideja.

Počev od Turinga (1950), kao kriterij za procenu inteligentnog ponašanja računara uzima se sposobnost verbalnog opštenja nalik ljudskoj, tzv. Turingov test (cf. Božović 2015). Ovde ćemo bliže razmotriti glasoviti Turingov test $i$ epistemološke osnove njegove, tako što ćemo ga dovesti u vezu s teorijama roda i intelektualnom istorijom XX veka. Pokazaćemo kako je Turing, oslonjen na svoje bihejviorističko shvatanje inteligencije, nagovestio koncept performativnosti jezika i roda nekoliko decenija pre tzv. (drugog i) trećeg talasa feminističke teorije - mogući tako jednako da doprinese razumevanju društvenog konstruktivizma druge polovine $X X$ veka kao i drugi suvremeni pristupi poput Wittgensteinova „jezičkog zaokreta", Austinove pragmatičke filozofije jezika ili feminizma de Beauvoir - te kako u skladu s time i sama Turingova merila jezičke kompetencije i inteligentnog ponašanja ljudi i računara treba razumeti fluidnije.

Početkom 2017, Centar za kvir studije iz Beograda održao je seriju naučnopopularnih tribina posvećenih "Velikanima nauke i umetnosti i njihovoj zanemarenoj (homo)seksualnosti“, rezultat koje je i istoimeni
\end{abstract}


zbornik radova (Maljković 2017). U jednom od razgovora, posvećenom Alanu Turingu, učestvovali su Ana Ješić, Slobodan Bubnjević i Đorđe Božović, a razgovor je moderirao Dušan Maljković. Pored Turingove lične i intelektualne biografije i njegovog znamenitog doprinosa dešifrovanju nacističke „Enigme“ tokom Drugog svetskog rata (v. sada Ješić 2017), jedno od pitanja koje je tom prilikom postavljeno jeste postoji li veza između Turingove homoseksualnosti i njegovog naučnog opusa; kako se u zborniku navodi: „cilj našeg projekta bio je da promovišemo ove stvaraoce i njihov rad, sa posebnim naglaskom na to kako je na njihov život i stvaralaštvo uticala njihova seksualna različitost" (Maljković, ibid.: 10). To pitanje utoliko je interesantnije što nije reč o stvaraocu u oblasti društveno-humanističkih nauka ili umetnosti, već o matematičaru i informatičaru, jednom od začetnika digitalne revolucije i njenom vodećem teoretičaru. Kako su prirodne i tehničke nauke obično i danas shvaćene izrazito pozitivistički, to se pitanje takve društvene uslovljenosti njihovih koncepata i paradigmi retko postavlja. Ipak, čini se da ga je u teorijama veštačke inteligencije (AI) nemoguće izbeći, za šta je zaslužan upravo sâm Turing.

Turingov test zasniva se na tzv. igri imitacije, kakva se u prvoj polovini veka obično igrala na kućnim zabavama u Britaniji. Igrač u ulozi „sudije“ ima zadatak da komunicirajući ceduljama sa dvoje ljudi - muškarcem i ženom - koje ne vidi pogodi ko je od njih žena. Kako bi igru otežao, muškarac u ovome paru pokušava da zavede „sudiju“ na krivi trag. Ako bismo muškarca zamenili mašinom koja bi igrala po istim pravilima, i ako bi mašina jednako uspela da prevari "sudiju“ kao što to s muškarcem u ovoj igri obično bude, za mašinu bismo mogli jednako da kažemo da ispoljava inteligentno ponašanje ravno ljudskom. Ovakvo shvatanje inteligencije sasvim je utemeljeno u tada dominantnoj bihejviorističkoj paradigmi (cf. Block 1981). Turing ga i predlaže kao alternativu pitanju „mogu li računari da misle“, koje postavlja na početku rada samo da bi ga odmah odbacio kao irelevantno (Turing, ibid.: 433-434). Za Turinga, dakle, od važnosti nisu unutrašnja mentalna stanja bilo čoveka, bilo mašine - ako takva uopšte postoje - već verbalno ponašanje koje omogućava uspešnu obmanu.

Podeljena su, međutim, shvatanja o važnosti rodne komponente u Turingovom testu (v. Shah \& Warwick 2016; Sterrett 2000; Genova 1994; cf. i komentare uz Turing 2009). Jasno je da, s jedne strane, računar ima zadatak da se (jezički) ponaša kao ljudsko biće, ali nije najjasnije koliko je 
važno da pri tome nužno imitira i ženu (ili tačnije, muškarca koji imitira ženu, dakle kao „mašinski transvestit", kako navode Hayes \& Ford 1995, u jednom od pokušaja Al da odbaci Turingov test kao evaluaciono sredstvo). Čini se, ipak, da veza između inteligentnog računara i društvene konstrukcije roda nije uopšte arbitrarna. Po Stevensu, igra imitacije nije tek jedan mogući primer Turingovog testa, već je upravo u njoj implicitno sadržana tvrdnja da je „rod ono paradigmatično znanje o svetu koje računar treba da usvoji" kako bi mogao da ispolji ljudsko ponašanje (Stevens 1994: 425); a s druge strane, računarska metafora nije i bez veze sa razumevanjem roda i telesnosti uopšte u istoriji ideja XX veka (cf. Bayer 2001; takođe Halberstam 1991; 1998). Na izvestan način, dakle, mada naravno ne zna za terminološku razliku, Turingu već sada nije strano ono konstruktivističko mišljenje o rodu i njegovo razlikovanje od biološki zadanog pola kakvo će uskoro obeležiti i tzv. drugi talas feminizma u nastajanju. Ono je upravo imanentno njegovom bihejviorističkom shvatanju ljudske prirode, koje mu i omogućava da zamisli robota koji ispoljava ljudsko ponašanje, pošto telesnost kao biološku datost ne povezuje nužno sa verbalnim dispozicijama koje je ona u stanju da proizvede.

Time što pak jezičko ponašanje daje kao kriterij za procenu inteligentnog ponašanja računara, Turing se čini svesnim da je ono performativno, slično kako ga vidi i Austin (1962). Sami računarski programi po sebi su performativni (Mackenzie \& Vurdubakis 2011), pa je taj koncept već u osnovi Turingove „univerzalne mašine“, tj. digitalnog računara (Turing 1950: 434-442). Imajući u vidu da računar ne samo što u igri imitacije treba da imitira rod, već i da ga performira jezikom, Turing ujedno anticipira i one ideje koje će kasnije pokrenuti tzv. treći talas queer i feminističke teorije (e.g. u Butler 1990; i dr.), svakako zahvaljujući i sopstvenoj „nevolji s rodom" (cf. Foster 1996: 300; o Turingovoj queer retorici v. sada i Fancher 2018). I ovde je, izgleda, od presudne važnosti Turingov bihejviorizam, koji mu omogućava da jezik shvati kao verbalno ponašanje koje se može imitirati, pa tako i performirati, a ne kao posebnu kognitivnu sposobnost. lako, međutim, bihejvioristički odbacuje mentalizam u psihologiji, sâm Turingov program Al jeste reprezentacionalistički i predstavlja vrstu računske teorije uma, kao uostalom i kognitivizam Chomskog, pa je utoliko nesretnija njegova prerana smrt 1954. godine, tek nekoliko godina pre nego što će Chomsky pokrenuti kognitivnu revoluciju u drugoj polovini XX veka (e.g. Chomsky 1959; inter alia). 
Jer, upravo po tome je za lingvistiku naročito bremenita Turingova koncepcija Al. Osim što primećuje da je rod (kao i druge društvene kategorije) društveno konstruisan, za Turinga je on i diskurzivan, dakle nošen (isključivo!) jezikom, čijom se pažljivom analizom može doći i do istinitog podatka o polu odnosno drugim karakteristikama govornika. Ako je samo na osnovu verbalnih podataka moguće (ili ne) zaključiti rod govornika u igri imitacije, ili i druge društvene odlike poput regionalne ili etničke pripadnosti, uzrasta, zanimanja itd., onda je jezik mnogo više od autonomnog sistema jezičkih pravila i reprezentacija. Za pristupe jeziku poput fonetike, dijalektologije, sociolingvistike, antropološke lingvistike ili forenzičke lingvistike, to je i aksiom - mada i jednako ne bez problema kao god što je i izvan jezika (cf. Božović 2014) - ali sledeći Turinga do kraja, to bi jednako trebalo da važi i za one „čvršće“ oblasti lingvistike poput teorijske (sistemske) lingvistike, psiholingvistike i sl.

Naime, takva Turingova posthumanistička, queer koncepcija duha omogućava i da samu jezičku kompetenciju i inteligentno ponašanje ljudi kao i računara shvatimo fluidnije. U središtu dominantne teorije jezičke kompetencije, kakva je ona Chomskog (e.g. u Chomsky 1965; 1986), nalazi se idealizovani izvorni govornik internalizovanog (I) jezika, zaokruženog sistema pravila i reprezentacija kojima suvereno vlada, čije je znanje o jeziku deklarativno i kategorično, jer je introspekcijom u stanju da vrši procene gramatičnosti nad svim iskazima. Nije čudo što nijedan računarski program do sada nije uspeo zaista da položi Turingov test, da u konverzaciji sa ljudskim „sudijom“ demonstrira takvo vladanje jezikom kakvo poseduje idealni izvorni govornik. Najskoriji primer - program nazvan „Eugene Goostman“, uspeo je da zavara tek trećinu ljudskih „sudija“ s kojima je razgovarao (Ješić, ibid.: 58-59), i to samo zato što se predstavlja kao trinaestogodišnjak iz Ukrajine, pa svoje neznanje o svetu i nevešte odgovore pravda time što mu je tek trinaest godina, a svoj negramatičan engleski time što mu ovaj nije maternji jezik. Ali, iako se „Eugenu“ to odmah i zamerilo kao pokušaj prevare, treba primetiti da prevare nema - ako zaista postoje i takva ljudska bića koja su trinaestogodišnjaci iz Ukrajine, koji nevešto i ne uvek smisleno komuniciraju na lošem engleskom, zašto onda ne bi bilo i robota koji ih impersoniraju?

$\mathrm{U}$ tome je i sukob između dominantne i Turingove diskurzivne koncepcije jezičke kompetencije i Al. Za Turinga, naime, ni roboti ne treba 
da budu idealni ljudi, kao što i nema idealnih ljudskih bića (što bi uvek nužno podrazumevalo srednjoklasnog, heteronormativnog, „belog“, sveznajućeg i bezgrešnog muškarca ili ženu, ideal koji uostalom ni sâm Turing nije zadovoljavao, zbog čega je i nesretno stradao). Nijedan robot ne uspeva da zadovolji taj ideal, ali u Turingovoj igri imitacije se to i ne očekuje, jer i robot, kao i čovek u društvu, treba da impersonira ženu ili „transvestita“ (tj. muškarca koji jednako nevešto impersonira ženu kao i muškarac u pravoj igri imitacije sa ljudskim subjektima). Utoliko ni jezička kompetencija, tj. verbalno ponašanje kojim se ona ispoljava, ne može odgovarati idealizovanom I-jeziku, već mora i sama da se opire tome idealu. Za melanholika Turinga, na kraju, postoji samo idealna mašina (po matematičkim i programerskim zakonima i merilima koja važe za mašine); nikada i idealna ljudska bića. Prema tome, letvicu koju dominantni pristupi Al drže tako visoko kada procenjuju performansu programa poput „Eugena“, dečka iz ratom zahvaćene Ukrajine kome engleski nije maternji jezik, verovatno ne bi mogla da dosegnu ni mnoga od ljudskih bića. 0 tome sâm Turing, komentirajući glasoviti Gödelov problem, ovako kaže:

The short answer to this argument is that although it is established that there are limitations to the powers of any particular machine, it has only been stated, without any sort of proof, that no such limitations apply to the human intellect. But I do not think this view can be dismissed quite so lightly. Whenever one of these machines is asked the appropriate critical question, and gives a definite answer, we know that this answer must be wrong, and this gives us a certain feeling of superiority. Is this feeling illusory? It is no doubt quite genuine, but I do not think too much importance should be attached to it. We too often give wrong answers to questions ourselves to be justified in being very pleased at such evidence of fallibility on the part of the machines. Further, our superiority can only be felt on such an occasion in relation to the one machine over which we have scored our petty triumph. There would be no question of triumphing simultaneously over all machines. In short, then, there might be men cleverer than any given machine, but then again there might be other machines cleverer again, and so on. (Turing, ibid.: 445) 
Stoga je i Turingova originalna zamisao Al daleko više humanistička i antropološka nego što je to „tvrda“ pozitivistička paradigma. U njoj se, naime, nalaze kako ključne ideje iz strukturalističkih paradigmi toga vremena, tako i zameci poststrukturalističkih teorija koje će XX vek tek doneti nekoliko decenija kasnije. $U$ intelektualnim istorijama XX veka, Turinga treba uvrstiti u red onih teoretičarki i teoretičara poput Wittgensteina, Quinea, Austina ili de Beauvoir, koji su razvili koncepte na kojima će počivati naredno razdoblje, te ga se s pravom može smatrati pretečom teoretičarki s kraja stoleća, poput Butler i dr. U istorijama feminizma i queer teorije, utoliko je Turingovo mesto i više opravdano.

$\mathrm{S}$ druge strane, upravo te humanističke ideje motivisale su i oblikovale dalji razvoj Al i samu digitalnu revoluciju koja će ubrzo uslediti. IIustrujmo to ovim programskim rečima Boringa, drugog teoretičara bihejviorizma s početka veka i takođe jednog od preteča Al, čiji je pristup pak sasvim utemeljen u logičkom pozitivizmu: „Certainly a robot whom you could not distinguish from another student would be an extremely convincing demonstration of the mechanical nature of man and of the unity of the sciences“ (Boring 1946: 191). Da se u ovom jednosmernom ,jedinstvu nauka" u osnovi nalaze prirodne i tehničke nauke ne treba posebno dokazivati - dovoljno je podvući razliku između Boringove „mehaničke prirode čoveka“ i Turingove humane prirode čoveka i mašine. I mada su i Turing i bihejviorizam ubrzo zauvek napustili ovaj svet, istorija je htela da kako kognitivne, tako i računarske nauke ipak krenu ovim drugim putem.

\section{Izvori i literatura}

Austin, John L. How to Do Things with Words: The William James Lectures delivered at Harvard University in 1955. Oxford: Oxford University Press, 1962. Print.

Bayer, Betty M. “Plugged In: Psychology, Technology and Popular Culture”. John R. Morss, Niamh Stephenson and Hans van Rappard (eds.). Theoretical Issues in Psychology: Proceedings of the International Society for Theoretical Psychology 1999 Conference. Dordrecht: Kluwer Academic Publishers, 2001. 23-34. Print.

Block, Ned. "Psychologism and Behaviourism". The Philosophical Review 90.1 (1981): 5-43. Print.

Boring, Edwin G. "Mind and Mechanism". The American Journal of Psychology 59.2 (1946): 173-192. Print.

Božović, Đorđe. „Turingov problem: jezičke tehnologije i lingvistička epistemologija“. 
Култура и/или наука

Aleksandra Vraneš i Ljiljana Marković (ur.). Digitalna humanistika, knj. 2. Beograd: Filološki fakultet, 2015. 199-206. Štampano.

Božović, Đorđe. „Jezik i seksualnost: konstrukcije i dekonstrukcija rodnih identiteta u sociolingvističkim i antropološkim istraživanjima“. Primenjena lingvistika 15 (2014): 143-151. Štampano.

Butler, Judith. Gender Trouble: Feminism and the Subversion of Identity. New York and London: Routledge, 1990. Print.

Chomsky, Noam. Knowledge of Language: Its Nature, Origin, and Use. New York: Praeger, 1986. Print.

Chomsky, Noam. Aspects of the Theory of Syntax. Cambridge, MA: MIT Press, 1965. Print.

Chomsky, Noam. "Review of B. F. Skinner's Verbal Behavior". Language 35.1 (1959): 2658. Print.

Fancher, Patricia. "Embodying Turing's Machine: Queer, Embodied Rhetorics in the History of Digital Computation". Rhetoric Review 37.1 (2018): 90-104. Print.

Foster, Thomas. "The Sex Appeal of the Inorganic': Posthuman Narratives and the Construction of Desire". Robert Newman (ed.). Centuries' Ends, Narrative Means. Stanford: Stanford University Press, 1996. 276-301. Print.

Genova, Judith. "Turing's Sexual Guessing Game". Social Epistemology 8.4 (1994): 313326. Print.

Halberstam, Judith. Female Masculinity. Durham: Duke University Press, 1998. Print.

Halberstam, Judith. "Automating Gender: Postmodern Feminism in the Age of the Intelligent Machine". Feminist Studies 17.3 (1991): 439-460. Print. Also reprinted in: Patrick D. Hopkins (ed.). Sex/Machine: Readings in Culture, Gender, and Technology. Bloomington: Indiana University Press, 1998. 468-483. Print.

Hayes, Patrick and Kenneth Ford. "Turing Test Considered Harmful". Chris S. Melish (ed.). Proceedings of the Fourteenth International Joint Conference on Artificial Intelligence, vol. 1. San Francisco: Morgan Kaufmann Publishers Inc., 1995. 972-977. Print.

Ješić, Ana. „Alan Tjuring - prvorodni greh veštačke inteligencije“. Dušan Maljković (ur.). Velikani nauke i umetnosti i njihova zanemarena (homo)seksualnost. Beograd: Centar za kvir studije, 2017. 49-62. Štampano.

Mackenzie, Adrian, and Theo Vurdubakis. "Codes and Coding in Crisis: Signification, Performativity and Excess". Theory, Culture \& Society 28.6 (2011): 3-23. Print.

Maljković, Dušan (ur.). Velikani nauke i umetnosti i njihova zanemarena (homo)seksualnost. Beograd: Centar za kvir studije, 2017. Štampano.

Shah, Huma, and Kevin Warwick. "Imitating Gender as a Measure for Artificial Intelligence: Is it Necessary?". Jaap van den Herik and Joaquim Filipe (eds.). Proceedings of the 8th International Conference on Agents and Artificial Intelligence, vol. 1. Setúbal: SciTePress - Science and Technology Publications Lda., 2016. 114119. Print.

Sterrett, Susan G. "Turing's Two Tests for Intelligence". Minds and Machines 10.4 (2000): 541-559. Print. Also reprinted in: James H. Moor (ed.). The Turing Test - the Elusive Standard of Artificial Intelligence. Dordrecht: Kluwer Academic Publishers, 2003. 79-97. Print. 
Stevens, Tyler. "'Sinister Fruitiness': Neuromancer, Internet Sexuality and the Turing Test." Studies in Novel 28.3 (1996): 414-433. Print.

Turing, Alan. "Computing Machinery and Intelligence". Robert Epstein, Gary Roberts and Grace Beber (eds.). Parsing the Turing Test: Philosophical and Methodological Issues in the Quest for the Thinking Computer. Dordrecht: Springer, 2009. 23-66. Print.

Turing, Alan. "Computing Machinery and Intelligence". Mind 59.236 (1950): 433-460. Print.

\section{Đorđe Božović}

University of Belgrade

Faculty of Philology

\section{GENDER AND LANGUAGE AND MACHINE INTELLIGENCE}

\section{Summary}

The paper emphasises the social bases of Turing's epistemology of machine intelligence. It is shown how Turing's idea of intelligent machines is closely related to the concept of performativity in the domain of language and gender, that is, how scientific paradigms are motivated and constructed by ideas from the humanities and culture.

Key words: the Turing test, social epistemologies, linguistic epistemology, gender and performativity, history of ideas. 